\title{
CHINESE SOFT POWER APPROACHES TOWARDS PAKISTAN: AN ANALYSIS OF SOCIO, ECONOMIC AND POLITICAL IMPACTS
}

\author{
Mehmood Hussain and Sumara Mehmood
}

\begin{abstract}
Pakistan has been facing imminent socio-economic, political and diplomatic challenges since 2001. The on-going war on terror has cost losses of infrastructure in the country amounting to $\$ 60$ billion. China has employed its own version of soft power ranging from diplomatic support on crucial issues, to foreign aid and investment, cultural exchanges and higher education opportunities for Pakistani youth. Among them, one of the most important projects is the construction of the China-Pakistan Economic Corridor (CPEC) with a total investment of $\$ 62$ billion. Against this backdrop, this study intends to highlight how China is projecting its soft power in Pakistan and to what extent Chinese soft power could heal Pakistan's socio, economic, political and diplomatic disasters. This study reveals that Chinese soft power strategies have left far higher imprints on Pakistan through diplomatic support, investment, and provision of scholarships.
\end{abstract}

Keywords: China-Pakistan relations, soft power, higher education exchanges, Confucius institutes, CPEC

\section{INTRODUCTION}

There is plenty of literature on China-Pakistan military and nuclear partnership, however not much has been written on Chinese soft power exercise over Pakistan. Since the past decade, the bilateral friendship has expanded its scope from the narrow perspective of military and nuclear cooperation to a more extensive various soft power strategies. Joseph Nye articulated the concept of soft power in the 1990s and some claimed that it is a Western concept. Nye (2004) argued that soft power "is the ability to get what you want through attraction rather than coercion or payments". According to him, three dimensions differentiate soft power from hard power. First, is culture - referring to the admiration and fascination on other societies. Second, refers to political values which are derived from a country's persistent and coherent pursuit of its values at home and abroad. Third, refers to the skill and intelligence of national diplomatic efforts. Soft power influence could be increased if target entity admires the important aspects of the country.

The development of Chinese soft power dated back to as early as 1993. Wang Huning, a member of the Communist Party of China (CPC), Central Committee and political advisor to former Chinese President Jiang Zemin, argued that Chinese culture - i.e., traditional Chinese and Confucian values, should be embedded and infused into its foreign policy (Huang, 2013). In his words, "if a country has an admirable culture and ideological system, other countries will tend to follow it. It does not have to use its hard power which is expensive and less efficient" (cited in Murphy, 2009). Against the wider background of the debate, two main schools of thought emerged on Chinese soft power. The mainstream encompasses the leading Chinese sociologists and 
philosophers who gave centrality to "culture" in the development of soft power. Whereas the minority view, while not denying the importance of culture, concluded that political power is the core of soft power (Murphy, 2009). Consequently, soft power was identified as a national policy in a political report to the $17^{\text {th }}$ National Congress of the CCP. The report urged China "to enhance culture as part of its soft power to better guarantee the people's basic cultural rights and interests" (Jintao, 2007).

Joshua Kurlantzick (2006) inscribed Chinese soft power in this way, "In the context of China, both the Chinese government and many nations influenced by China enunciate a broader idea of soft power than did Nye. For the Chinese, soft power means anything outside of the military and security realm, including not only popular culture and public diplomacy, but also more coercive economic and diplomatic levers like aid and investment and participation in multilateral organizations that are Nye's carrots and sticks". This broader definition of soft power has been discussed by eminent Chinese scholars as an element of a nation's "comprehensive national power" (zonghe guoli). They argue that this is an area where China has some leverage vis-àvis the United States (U.S.). Since March 2004, China has set clear goals to use public diplomacy to promote Chinese soft power. In China, public diplomacy is a foreign concept. Chinese usually use the term dui wai xuan chuan or wai xuan (external propaganda). Unlike the English translation, in Mandarin Chinese, xuan chuan (propaganda) has a positive connotation with benign activities such as release of news, general shaping of ideology and advertisement (Wang, 2008). The Propaganda Division in the Ministry of Foreign Affairs is firmly committed to promoting Chinese benign image through advertisements of Chinese achievements and boosting the country's image overseas. Beijing has been systematically redressing the so called China threat theory by emphasizing both political and public diplomacy.

Chinese soft power strategy rests on the establishing of a 'harmonious society' at home and a 'harmonious world' globally (Murphy, 2009). In 2008, it articulated its own theoretical basis for soft power with a combination of modern Marxist and ancient Confucian thoughts through the introduction of four trillion RMB to mitigate impacts of the 2008 financial crisis and stability of its domestic market. China also realizes the critical role of higher education in the projection of its soft power. So, it is expanding its global influence through the promotion of international exchanges and collaborations in higher education by establishing Confucius Institutes (CIS), and inviting talented youths from overseas to pursue higher education in Chinese universities (Yang, 2010).

\section{CHINESE DIPLOMATIC UMBRELLA}

By most accounts, diplomatic exchanges between Islamabad and Beijing are presented as to praise friendship between two great nations. Leadership of both countries describe the relationship in poetic and effusive ways. For instance; "Higher than the mountains, deeper than the oceans, sweeter than honey, and stronger than steel". Since the inception of diplomatic relations in May 1951, China and Pakistan have maintained cordial relations, and top tier leadership of both sides have exhibited ascendency of diplomatic relations. This is due to four reasons. First, Pakistan considers China as an all-weather friend. Second, is on self-reliance - where China transfers military technology to Pakistan to accomplish self-reliance goals in areas of 
defence and nuclear technology. Third, is to counter Indian threat, and fourth, is the joint efforts against terrorism (Siddique, 2014).

It is worth mentioning here that China has widened its diplomatic umbrella to Pakistan on many crucial issues including Kashmir, cross border terrorism, drone attacks, and the U.S. Marine attack in Abbottabad. Kashmir is an unsettled agenda on India's partition plan and is a source of persistent rivalry between India and Pakistan. With respect to Kashmir, back in 1964 Chinese Premier Chou En-lai had issued a joint communique with President Ayyub Khan expressing hope that the Kashmir dispute would be resolved in accordance with the wishes of people of Kashmir as pledged to them by India and Pakistan (Amin, 2017). Chinese position was reaffirmed later in a joint communique issued after Ayyub Khan's visit to China in 1965. In November 1970, China again made its position clear in supporting the Kashmiri people's right of self-determination during President Yahiya's visit. Soon after the disintegration of Pakistan in the 1971 Indo-Pak war, Chinese Premier Chou En-lai and the U.S. President Richard Nixon issued a joint communique in February 1972 in which China reiterated its support to the people of Kashmir "in their struggle for the right of self-determination". However, the dilution in China's open support for Pakistan on the Kashmir issue took place in the 1980s with Sino-India rapprochement. Since then, China has made no specific reference to support Pakistan over Kashmir, but at the same time it refuses India's claim that Kashmir is an integral part of India. It states that China has clear and consistent stance that Kashmir is a leftover issue from history and should be addressed through bilateral dialogues between relevant parties (Patranobis, 2017).

Cross border terrorism is another source of contention between India and Pakistan. Whenever a terrorist incident occurs in India, New Delhi would accuse that Pakistan-based organizations are involved. But, contrary to the facts, India's allegations are part of India's plan to isolate Pakistan on international forums. To counter India's act of isolation, Beijing would save Islamabad through the extension of its diplomatic umbrella. For instance, in April 2006, Beijing had opposed the IndoU.S. resolution in the UNSC to designate Lashkar-e-Taiba and Jammat-ud-Dawa outfits of international terrorism. Again, in May 2007, China blocked the Indo-U.S. initiative in the UNSC to put sanctions on Pakistani led organizations and individuals (Siddiqui R. A., 2014). In the wake of the November 2008 terrorist attack on Taj Hotel India, New Delhi had accused Pakistani intelligence agency to have assisted Jammat-ud-Dawa, and submitted an initiative in the UNSC to designate Jammat-udDawa as an international terrorist organization. However, China had blocked India's move on behest of Pakistan (Small, 2010). Pakistan had then released Zaki-urRehman Lakhvi, a key commander of Lashkar-e-Taiba in 2015. India had questioned the bail and brought a bid to the UNSC, but faced embarrassment again after China vetoed against it (Singh, 2016).

Here, questions emerged - why does Beijing support Pakistan, and why is Islamabad important to China? Pakistan is a country that has territorial disputes with India, but also has strategic significance to Beijing. Back in the 1960s, mutual enmity with India had pushed both nations closer, which resulted in an all-weather friendship. To check India's power, Beijing has always supported Pakistan on military and diplomatic fronts. Secondly, Pakistan is a country which can provide China access to the Indian Ocean through Gwadar Port. Pakistan's support for China in the 
Organization of Islamic Cooperation (OIC) and Non-Aligned Movement (NAM) could be another reason for Beijing extending support to Pakistan. A third reason could be India's strategic partnership with the United States which China sees as a major challenge. India's close relations with the United States in the past decade has been seen by Beijing as a counterweight to China in Asia (Roche, 2016).

After the successful agreement of the CPEC, China described Gilgit Baltistan region as part of Pakistan - a region, which according to India is a disputed territory between India and Pakistan, but is under actual control of Pakistan (Sharma, 2014). The comments made by the Chinese Ministry of Foreign Affairs fuelled India's anger and its opposition to the CPEC. Since its earlier announcement in 2013, India has raised concerns over the CPEC route passing through Kashmir and Gilgit Baltistan and Chinese profound involvement in Pakistan.

Pakistan is one of the countries most affected by terrorism and extremism since the late 1980s, and it has been playing frontline role in war against global terrorism since 2001. Despite its unparalleled sacrifices, the U.S. has often accused Pakistan of supporting terrorism. On $2^{\text {nd }}$ May 2011, the U.S. Navy Seals had killed Osama bin Laden in his compound near an Army garrison in Abbottabad, Pakistan (Miller, 2011). The act was a profound violation of Article 2(4) of the United Nations Charter which prohibits the use of threat or force in international relations. The U.S. was said to have violated the said article which calls for member states to respect the sovereignty, territorial integrity and political independence of other states (United Nations, 1945). This act had led to the severance of diplomatic relations between Washington and Islamabad. China had strongly condemned the U.S. violation, and in one of his statements, Premier Wen Jiabao stated that "Pakistan has made huge sacrifices and important contributions to the international fight against terrorism, that its independence, sovereignty, and territorial integrity must be respected, and that the international community should understand and support Pakistan's efforts to maintain domestic stability and to realize economic and social development" (Pant, 2012). The Chinese diplomatic support had lessened the trauma and Pakistan's vulnerability in defending the country, and had rejuvenated the confidence in policy makers.

\section{HIGHER EDUCATION COLLABORATION}

China is expanding its gambit across the globe through systemically planned soft power instruments, and educational exchanges fall under this rubric of soft power. Beijing is skilfully providing scholarships to foreign students to learn Mandarin and to pursue higher education in Chinese universities (Yang, 2015). Winning hearts and minds remain an important component in its international higher education system. Training future generations of political elites, intellectuals and technicians from other nations is an important form of soft power, and China is pursuing exactly this. Beijing is hosting students from all over the world, particularly from developing states. According to Chinese Ministry of Education, the number of foreign students in China from 178 countries has remarkably increased from 36,000 over the past decades to 210,000 in 2016. Pakistan has jumped from being the ninth largest recipient to the fourth with approximately 19,000 students studying in Chinese universities (Dawn News, 2016). 
Table 1: Chinese Government Scholarships for Pakistani Students from 20072015

\begin{tabular}{ccc}
\hline Year & Number of Students & Percentage \\
\hline 2007 & 4,450 & 2.30 \\
2008 & 5,199 & 2.30 \\
2009 & 5,738 & 2.40 \\
2010 & 7,406 & 2.80 \\
2011 & 8,516 & 2.90 \\
2012 & 9,522 & 2.90 \\
2013 & 10,941 & 3.01 \\
2014 & 13,360 & 3.50 \\
2015 & 15,654 & 3.90 \\
\hline
\end{tabular}

Source: Project Atlas ${ }^{\circledR C h i n a}$ from China Scholarship Council

Pakistan is a developing country lacking in substantial funds for research and development. Except for a few, the majority of Pakistani universities have no access to state of the art laboratories which are considered nurseries for innovation and development (Khan U. A., 2016). To bridge the gap in innovation and technology, in April 2005, the Higher Education Commission (HEC) of Pakistan signed a memorandum of understanding with China's Scholarship Council. In accordance with the memorandum, from 2005 to 2009 the HEC had financed doctoral degrees of 1,000 college teachers and scientific researchers in Chinese universities (HEC, 2005). International collaboration was viewed as a tool to expand educational exchanges. During the visit of the Chinese President Xi Jinping in April 2015 to the National University of Modern Languages Pakistan (NUML), Xinjiang Normal University, Urumqi China signed a Memorandum of Understanding (MoU) on cooperation in higher education under which both stakeholders would host exchange visits of students and faculty members. NUML also signed an additional agreement to establish NUML International Centre of Education (NICE) at Xinjiang Normal University. The agreement will enable NUML University to set up its international campus in China, which will open new vistas for Chinese and Pakistani students to share knowledge and culture in an international environment (Institute, 2015). Similarly, a number of Chinese universities have set up Pakistan study centres to learn about the Pakistani state, society, culture, politics and economy. It is also worth to mention here that Chinese Universities are also promoting Urdu, the national language of Pakistan. According to China Economic Net, admissions are open in Urdu Department of Beijing Foreign Studies University. The university admits 20 students every four years to learn the Urdu language. Similarly, Xian International Studies University and Guangdong University of Foreign Studies have opened Urdu departments and have more students than the Beijing Foreign Studies University (Tribune, 2016).

\section{Confucius Institutes}


The National Office for Teaching Chinese as a Foreign Language (Hanban) is responsible in establishing Confucius Institutes and teaching Mandarin and Chinese culture across the globe. The first Confucius Institute was established in Seoul (South Korea) in November 2004 (Yang, 2015). A total of 439 Confucius Institutes had been established in 127 countries and regions in the world at the end of 2013. Confucius Institutes are fulfilling the desire and passion of people around the world to learn Mandarin and promoting friendship between China and the rest of the world (Yang, 2010). China-Pakistan entered into an agreement to establish Confucius Institutes in April 2005, and the first Confucius Institute in Pakistan was established at NUML University Islamabad on $9^{\text {th }}$ April 2007, with the collaboration of Beijing Language and Culture University China and Confucius Institute Headquarter (CII) (China.Org.Cn, 2007). The CII articulated its aims as to meet increasing demand to learn Chinese language in Pakistan and to promote cultural heritage in a Muslim majority state. CII appealed students from all walks of life to learn Mandarin, culture, kung fu, calligraphy, music, among others. According to a CII report in 2013, more than 6,000 students had been admitted to learn Chinese language and 31 teaching points had been established from primary schools through to university level (CII, 2005).

Professor Jiang Yinlian, the Director of the Confucius Institute in Bangladesh argues that the learning of language is a durable bridge to enhance bilateral relations and decreasing the cultural gap with people of different countries in the world (CRI Confucius Institute, 2010). The second Confucius Institute was established at the University of Karachi with the collaboration of Sichuan Normal University, China (Daily Times, 2016). The Confucius Institute at Karachi University is benefiting not only the population of the metropolis city, but also the people of Pakistan at large. After the successful conclusion of the CPEC, the Punjab government announced plans to send 500 students from Punjab to China to learn Mandarin. The selection process had been completed, and necessary training had already been provided to students by the CII (Observer, 2015). Roots International Schools have also established international departments of Chinese language. Roots schools are committed to equip future generation with Mandarin which is expanding its influence across the world (Schools, 2016). The China-Pakistan Institute is also a platform to promote Chinese language and culture in Pakistan. Approximately 4,000 students learnt the Chinese language through its platform and an online program was also introduced for distance learning education (Nihao Salam, 2016). It is the Chinese soft power characteristics that a resolution in the Upper House (Senate) of Pakistan was presented to declare Chinese as an official language and the resolution was approved, but the house chairman had stressed that the Chinese language training will be given to those working on the CPEC projects and facing difficulties in communication (Niazi, 2018).

\section{TRADE, INVESTMENT AND AID}

Though military-nuclear collaboration is an enduring pillar of China-Pakistan friendship, the end of the Cold War saw both countries strengthening their economic and trade relations. Two-way trade reached $\$ 12$ billion in 2012 , but this still fell short of expectations. Pakistan was facing huge trade deficits whereby more than 75 percent of the two way trade consisted of Pakistani imports of Chinese goods, with only a few dollars' worth heading the opposite side (Small, 2015). To provide greater access to Pakistani goods in the Chinese market, earlier in November 2006, both countries had 
signed a Free Trade Agreement (FTA). Besides the FTA, China-Pakistan also established a free trade zone in the outskirts of Lahore to boost trade in goods and services as well as investment in Pakistan (Peoples Daily, 2009). In the past few years, China has invested more than $\$ 1.3$ billion in Pakistan. Chinese investments target telecommunications, energy, infrastructure, heavy engineering, information and technology, mining and defence related industries. Presently, Chinese ZTE, Huawei Technologies Co. Ltd, China National Machinery Import/Export Corporations, Metallurgical Construction Corporation of China, China International Water and Electric Corporation, China Petroleum and Haier are working in Pakistan in oil and gas, IT and telecom, power generation, engineering, automobiles, infrastructure and mining sectors (Memon, 2010).

Table 2: Pakistan's Imports and Exports to China from 2009-2015 in Rs. Billion

\begin{tabular}{|c|c|c|c|c|c|c|}
\hline Item & & & & & & $\begin{array}{l}\mathbf{2 0 1 4 - 1 5} \\
\text { (July- } \\
\text { March) }\end{array}$ \\
\hline Exports & $\mathbf{2 0 0 9 - 1 0}$ & $\mathbf{2 0 1 0 - 1 1}$ & $\mathbf{2 0 1 1 - 1 2}$ & $\mathbf{2 0 1 2 - 1 3}$ & $\mathbf{2 0 1 3 - 1 4}$ & 169.9 \\
\hline Imports & 370 & 139.7 & 195.9 & 252.5 & 249 & 776 \\
\hline
\end{tabular}

Source: Ministry of Finance, Government of Pakistan, and Economic Survey of Pakistan

In 2006, Chinese President Hu Jintao paid a state visit to Pakistan to attend the inauguration ceremony of Haier-Ruba Special Economic Zone (SEZ) with his Pakistani counterpart President General Pervez Musharraf. On the side-line, 13 joint venture agreements worth $\$ 3$ billion were signed between Pakistani and Chinese companies (Hartpence, 2011). Since the past decade, Chinese foreign direct investment (FDI) has significantly increased in Pakistan. Former Prime Minister Shoukat Aziz testified that Chinese FDI surpassed \$4 billion in 2004 and it continues to increase. Similarly, China is a source of aid, grants and loans to Pakistan. In 1979, Pakistan received $\$ 620$ million out of $\$ 4960$ million of Chinese aid. Soon after the October 2005 earthquake, Pakistan had organized a donors conference to reconstruct affected areas, where China donated $\$ 814$ million dollars (Kumar, 2006).

Table 3: Chinese FDI in Pakistan during 1999-2017

\begin{tabular}{cc}
\hline Year & Inflows (\$ Million) \\
\hline $1999-00$ & 10.5 \\
$2000-01$ & 0.1 \\
$2001-02$ & 0.3 \\
$2002-03$ & 3.0 \\
$2003-04$ & 14.3 \\
$2004-05$ & 0.4 \\
$2005-06$ & 1.7 \\
$2006-07$ & 712.1 \\
$2007-08$ & 13.7
\end{tabular}




$\begin{array}{cc}2008-09 & 101.4 \\ 2009-10 & 3.6 \\ 2010-11 & 47.4 \\ 2011-12 & 126.1 \\ 2012-13 & 90.6 \\ 2013-14 & 695.8 \\ 2014-15 & 255.3 \\ 2015-16 & 593.9 \\ 2016-17 & 718.3 \\ \text { July - April) } & \end{array}$

Source: Board of Investment, Government of Pakistan \& the State Bank of Pakistan, Handbook of Statistics on Pakistan Economy

China-Pakistan boosted their economic and investment partnership through the setting up of Joint Economic Commission, Economic Cooperation Group, Joint Energy Working Group and a Joint Investment Company. Frameworks in economic cooperation were also established, namely, the Framework Agreement on Expanding and Deepening Bilateral Economic and Trade Cooperation which was signed in February 2006. As a result of various agreements and frameworks, more than 120 Chinese companies and an estimated 10,000 Chinese engineers and workers are working in infrastructure and energy projects in Pakistan. Orient Group has invested more than $\$ 700$ million in the energy sector in Pakistan, which was hailed by former President Asif Ali Zardari in 2012 (Daily Times, 2012).

China had also come forward to rehabilitate Pakistan post natural disasters. In October 2005, Pakistan was hit by a devastating earthquake in which Kashmir, the Northern parts and the Capital territory were severely affected. According to government statistics, nearly 18,000 people perished and more than 41,000 were injured. China was the first country to lend assistance to Pakistan. In the first week, China provided $\$ 6.2$ million aid including 1,050,000 blankets, and 3,380 tents worth 50 million Yuan. Subsequently, Chinese assistance surpassed \$20.5 million. The Chinese aid greatly contributed to the reconstruction process (Naveed, 2014). In 2010, when Pakistan was hit by catastrophic floods which affected nearly 18 million people, China once again sent its medical teams and rescue missions to affected areas and provided $\$ 250$ million aid to Pakistan to recover from the floods.

\section{China-Pakistan Economic Corridor (CPEC)}

In recent years, China has employed economic statecraft strategy to project its soft power influence. An example of Chinese foreign economic policy is the development of One Belt, One Road (OBOR) which will directly influence 4.4 billion people with collective GDP of $\$ 2$ trillion. Once completed, it will connect China with Southeast Asia, the Indian Ocean, the Middle East, and ultimately, Europe (NDRC, 2015). Chinese Premier Li Keqiang visualized the idea of CPEC in May 2013 and an MoU was signed in Beijing in the same year in the presence of Chinese Premier Li Keqiang and Pakistani Prime Minister Nawaz Sharif. In April 2015, Chinese President Xi Jinping visited Pakistan and paved the way for the construction of mega projects with the conclusion of $51 \mathrm{MoUs}$ and agreements worth around \$46 billion (Bhattacharjee, 
2015). According to latest news, total investment in the economic corridor reached $\$ 62$ billion (Siddiqui S., 2017). The Chinese ambassador to Pakistan, Sun Weidong described it as the flagship project of Chinese grand investment strategy of OBOR ( $\mathrm{Li}, 2015)$. He stated that the CPEC is a long-term and systematic project to promote economic cooperation through collaboration on Gwadar Port, energy, infrastructure and industrial cooperation. The Prime Minister of Pakistan Nawaz Sharif labelled it "a game changer project" for Pakistan and South Asia (Esteban, 2016).

The proposed economic corridor will connect Pakistan's deep-sea Port of Gwadar to China's northwest province of Xinjiang with approximately 3,000kilometre network of roads, railways, and oil and natural gas pipelines (Talwar, 2015). Apart from roads and railways, 29 SEZs and industrial parks are proposed to be built along the project belt and for early harvest phase, 9 SEZs have been approved by Pakistan and China (CPEC, 2017). The economic corridor will deliver the much needed and sophisticated logistic infrastructure to Pakistan and will add roughly $17,000 \mathrm{MW}$ electricity to the national grid - ending Pakistan's rampant energy shortfalls (Bhattacharjee, 2015). Simultaneously, the corridor will provide safer and shortest overland route to Chinese energy shipments from the Persian Gulf and Africa through Pakistan and will save millions of dollars in shipment fees.

China is also embarked to invest $\$ 62$ billion in the CPEC and $\$ 34$ billion is already allocated to energy generation projects. The first phase is dedicated to the early harvest projects with total investments of $\$ 28$ billion including in energy and infrastructure development, and expected to be completed by 2018. The energy projects are combinations of coal, furnace oil, wind and hydro power plants (Shah, 2015). Pease see the table below for detailed observation of energy projects under the CPEC.

Table 4: CPEC Energy Priority Projects

\begin{tabular}{|c|c|c|c|}
\hline \# & Project Name & MW & $\begin{array}{l}\text { Estimated } \\
\text { Cost }(\$ \\
\text { M) }\end{array}$ \\
\hline 1 & $\begin{array}{l}\text { 2x660MW Coal-fired power plants at Port Qasim } \\
\text { Karachi }\end{array}$ & 1320 & 1,980 \\
\hline 2 & $\begin{array}{l}\text { Suki Kinari Hydropower Station, Naran, Khyber } \\
\text { Pukhtunkhwa }\end{array}$ & 870 & 1,802 \\
\hline 3 & Sahiwal 2x660MW Coal-fired Power Plant, Punjab & 1320 & 1,600 \\
\hline \multirow[t]{3}{*}{4} & $\begin{array}{l}\text { Engro Thar Block II 2x330MW Coal fired power plant } \\
\text { Tel 1x330MW Mine Mouth Lignite Fired Power Project } \\
\text { at Thar Block-II, Sindh }\end{array}$ & $\begin{array}{l}660 \\
330\end{array}$ & 2,000 \\
\hline & $\begin{array}{l}\text { Thal Nova 1x330MW Mine Mouth Lignite Fired Power } \\
\text { Project at Thar Block-II, Sindh }\end{array}$ & 330 & \\
\hline & $\begin{array}{l}\text { Surface mine in block II of Thar Coal field, } 6.5 \text { million } \\
\text { tons/year }\end{array}$ & & 1,470 \\
\hline 5 & $\begin{array}{l}\text { Hydro China Dawood 50MW Wind Farm (Gharo, } \\
\text { Thatta) }\end{array}$ & 50 & 125 \\
\hline 6 & $\begin{array}{l}\text { 300MW Imported Coal Based Power Project at Gwadar, } \\
\text { Pakistan }\end{array}$ & 300 & 600 \\
\hline 7 & Quaid-e-Azam 1000MW Solar Park (Bahawalpur) & 1000 & 1,215 \\
\hline
\end{tabular}




\begin{tabular}{|c|c|c|c|}
\hline 8 & UEP 100MW Wind Farm (Jhimpir, Thatta) & 100 & 250 \\
\hline 9 & Sachal 50MW Wind Farm (Jhimpir, Thatta) & 50 & 134 \\
\hline 10 & $\begin{array}{l}\text { SSRL Thar Coal Block-I } 7.8 \text { mtpa \& SEC Mine Mouth } \\
\text { Power Plant }(2 \times 660 \mathrm{MW})\end{array}$ & 1320 & 2,000 \\
\hline 11 & Karot Hydropower Station & 720 & 1,420 \\
\hline \multirow[t]{2}{*}{12} & Three Gorges Second Wind Power Project & 50 & 150 \\
\hline & Three Gorges Third Wind Power Project & 50 & \\
\hline 13 & $\begin{array}{l}\text { CPHGC 1,320 MW Coal-Fired Power Plant, Hub, } \\
\text { Balochistan }\end{array}$ & 1320 & 1,940 \\
\hline \multirow[t]{3}{*}{14} & Matiari to Lahore $660 \mathrm{kV}$ HVDC Transmission Line & & 1,500 \\
\hline & Project & & 1,500 \\
\hline & $\begin{array}{l}\text { Matiari (Port Qasim)-Faisalabad Transmission Line } \\
\text { Project }\end{array}$ & & \\
\hline 15 & $\begin{array}{l}\text { Thar Mouth Oracle Power Plant (1320MW) \& surface } \\
\text { mine }\end{array}$ & 1320 & 1,300 \\
\hline \multicolumn{4}{|c|}{ CPEC-Energy Actively Promoted Projects } \\
\hline 16 & Kohala Hydel Project, AJK & 1100 & 2,397 \\
\hline 17 & Rahimyar Khan imported fuel Power Plant 1320MW & 1320 & 1,600 \\
\hline
\end{tabular}

Source: Ministry of Planning, Development and Reforms, Pakistan

Although the CPEC has potentials for regional connectivity for South Asia and Central Asia through China, and has generated hyper nation in Pakistani leadership, it may face major challenges during and after the construction phase. The major threat is terrorism inside Pakistan which has destroyed and may potentially destroy human and physical infrastructure. Since 2001, a new wave of terrorism across the country has so far consumed 62,403 people including 21,890 civilians, 6,802 security forces personnel and 33,711 terrorists/insurgents in terror related incidents (SATP, 2017). The most vulnerable areas are FATA and Baluchistan where militants frequently target Chinese engineers and workers of development projects. An Uzbek speaking militant leader Mufti Abu Zar al-Burmi had appealed to all Taliban factions to target Chinese nationals (Sial, 2014). Another source of tension between federation units is route controversy. Major political parties in Khyber Pakhtunkhwa and Baluchistan strongly expressed their concerns over the route change. Asfand Yar Wali Khan, Awami National Party Chief, the mainstream political party in Khyber Pakhtunkhwa proclaimed that his party would continue the struggle for the restoration of the 'original' route which largely passes through Khyber Pakhtunkhwa. He further went on to call the CPEC project as the ChinaPunjab Economic Corridor project which largely bypasses other provinces of the country (Khan M., 2016). Controversies over route change not only threaten national cohesion of Pakistan, but it also sets alarm ring bells in Beijing over the success of the multibillion-dollar project, so much so that China has continuously pressured Islamabad to solve all necessary issues relating to the project route.

International Monetary Fund (IMF) has also called for transparency in projects executed under the umbrella of the CPEC. Officials from IMF insist that more information is needed on debts being taken on, and the future foreign exchange requirements for servicing these debts (Dawn News, 2016). Pakistan has raised special security forces of 15,000 paramilitary personnel to protect the project route. In September 2015, in an ECC meeting, the federal government decided that capital cost of all energy related projects under the CPEC should be raised by 1 percent to pay for 
the running costs of the security force, and it also decided to transfer the security costs onto consumers, and directed NEPRA to make the necessary arrangements (Hussain, 2016). Another issue is the confidentiality of the CPEC project agreement. Senate committee had inquired on the details of the project agreement, but was met with unexpected and irresponsible response from the former Federal Minister for Planning and Development, Ahsan Iqbal, who stated that the agreement was confidential and could not be made public (Khan R., 2016).

The above-mentioned issues are serious and may harm the CPEC projects in general and China-Pakistan relations in particular. Islamabad is required to take necessary measures to diminish the controversial theories on mega projects and it also needs to take into account the concerns from Beijing. Similarly, Beijing needs to be aware and understand the limits of Pakistani politics. Pakistan is a parliamentary democracy with multi-party politics, and the government is not in a position to take unilateral decisions without taking notice of other stakeholders in decision-making. Beijing and Islamabad need to work together to develop confidence in other entities of the country particularly Baluchistan and Khyber Pakhtunkhwa about their due share in the game changer project. At the same time, Islamabad must declassify documents pertaining to the agreement and invite policy makers and prominent experts to make neutral analysis for future costs and benefits. It is necessary to categorize direct investments, loans and grants, public, private investments and interest rates to be paid on it.

Despite the looming challenges and threats, rewards for Pakistan are potentially generous after the successful implementation of the CPEC. It will deliver modern and sophisticated infrastructure and will develop sustained economic growth. In longer term, it will generate millions of jobs for Pakistani youth, and will uplift millions of people from poverty (Kapoor, 2015). At the same time, it will be a source to counter separatist sentiments in China's much deprived province of Xinjiang through stable and steady economic growth and setting up new industrial zones. Beijing views that economic prosperity will change perceptions of its Uyghur nationals and they will abandon the struggle for separation. The head of the CPEC started from Xinjiang and Beijing has already kick-started projects with billions of investments and believes that economic prosperity will turn Uyghur loyalties with Beijing (The New York Times, 2015).

Table 5: CPEC Projects

\begin{tabular}{llll}
\hline \multicolumn{3}{c}{ CPEC: Energy Projects } \\
\hline No. & Name of Project & MW & Estimated Cost (US\$) \\
1. & Energy Priority Projects & 10,400 & 21,486 \\
2. & $\begin{array}{l}\text { Energy Actively Promoted } \\
\text { Projects }\end{array}$ & 6,645 & 12,927 \\
& & $\mathbf{1 7 , 0 4 5}$ & $\mathbf{3 4 , 4 1 3}$ \\
& & \\
\hline & & \\
\hline
\end{tabular}


1. KKH Phase II (Raikot-Islamabad Section)

2. Peshawar-Karachi Motorway (Multan-Sukkur

Section)

\section{Rail Sector}

1. Expansion and reconstruction of existing Line ML-1

$1,736 \quad 3,650$

2. Havelian Dry Port (450 M. Twenty Foot Equivalent Units)

\section{Total}

\section{CPEC: Gwadar Port Related Projects}

\begin{tabular}{llc}
\hline 1. & Eastbay Expressway & 140.60 \\
2. & Gwadar International Airport & 230.00 \\
3. & Construction of Breakwaters & 123.00 \\
4. & Dredging of Berthing areas \& Channels & 27.00 \\
5. & Infrastructure for Free Zone \& EPZs related & 32.00 \\
& industries & \\
6. & Necessary Facilities of Fresh Water Treatment \& & 130.00 \\
& Supply & 100.00 \\
7. & Hospital at Gwadar & 10.00 \\
8. & Technical \& Vocational Institute at Gwadar & $\mathbf{7 9 3 . 0 0}$
\end{tabular}

\section{CPEC: Other Projects}

1. Cross Border Fiber Cable 44

2. DTMB

Total

Total Cost of CPEC Projects

Source: Ministry of Planning, Development and Reforms, Pakistan

Sun Weidong, the Chinese Ambassador to Pakistan, stated that the CPEC was a long-term comprehensive cooperation framework covering broad range of sectors including roads, railways, telecommunication routes and people to people exchanges. He further claimed that the CPEC was a guarantee of peace and prosperity in Pakistan (Global Times, 2015). Similarly, Prime Minister Nawaz Sharif stated that the CPEC would provide equal benefits to all provinces and generate thousands of jobs and business opportunities across the country (Rediff News, 2015). A Chinese newspaper commented that Pakistan was expecting a cut in unemployment by 2.32 million with the activation of the CPEC-related projects within the next two years (Pakistan Today, 2017). A large proportion of jobs would come after the establishment of SEZs. Experts say the CPEC will prove to be a game changer project for economic and social development of Pakistan. But, statements about prosperity and economic development would come true only after major threats and challenges to the CPEC are countered. If Pakistan and China fail to root out internal and external threats, it is 
expected that the CPEC might escalate tensions in friendship of the two nations and also increase the economic and political tensions inside the polity.

\section{CULTURAL DIPLOMACY}

China is expanding its sphere of influence through systematically planned soft power strategies including through cultural diplomacy. Chinese diplomacy is enriched with its ancient cultural heritage, and Beijing is exporting it through an elaborated network of cultural exchanges and enterprises. For example, in 2004 China organized the Sixth Asia Arts Festival with almost 1,000 artist participants from 17 Asian countries, with more than 500,000 spectators attending the festival (Peoples Daily, 2004). A bilateral cultural agreement was signed on $26^{\text {th }}$ March 1965, to strengthen friendship between the people of the two countries through cooperation in the fields of culture, arts and science. The agreement opened the doors for exchange of educationists, scientists, experts and scholars, performing artists, journalists and broadcasting, television and film institutions of the two countries. Under the framework of cultural agreement, the Ministry of Radio and Television of China and the Ministry of Information and Broadcasting of Pakistan signed a separate agreement on $26^{\text {th }}$ February 1983, for the exchange of radio and television programmes between the two countries (MOFA PRC).

Since the conclusion of these agreements, Pakistan and China have maintained close cooperation in the sphere of culture, friendly exchanges and people-to-people contacts. A number of cultural delegations headed by senior officials of the two countries have visited each other during the last seven decades. Apart from government delegations, general public of the two countries are also engaged in exchange of arts, literature, education, information, sports, youth affairs, cultural relics, archives, publications, health and women's affairs, among others. Chinese art troupes including folk songs and dance troupes, traditional instrumental music troupes and acrobatic troupes have also visited Pakistan multiple times. In January 2004, 30 members of the Chinese Jiangxi Acrobatic troupe visited Pakistan and were cordially hailed by Pakistan (Chinese Consulate Karachi, n.d.).

President Xi Jinping's visit to Pakistan in April 2015 has paved the way for a new era of brotherly relations between the two states. During his stay in Pakistan, he stressed upon the need to deepen cultural ties and to boost press and media cooperation. As a result, an agreement was signed for cooperation between the State Administration of Press, Publication, Radio, Films and Television of China and Pakistan's Ministry of Information, Broadcasting and National Heritage. A tripartite agreement was signed between China Central Television and PTV and Pakistan Television Foundation for rebroadcasting of CCTV-News/CCTV-9 Documentary in Pakistan (Kiani, 2015). Further Protocol agreements were signed on the establishment of sister-cities relationship between Chengdu (China's Sichuan Province) and Lahore; Zhuhai (Guangdong Province) and Gwadar and Karamay (Xinjiang Uyghur) and Gwadar. 


\section{CONCLUSION}

Chinese soft power strategies have long lasting impacts on Pakistan's socio, economic and political conditions. Major segments of government and general public view China as an all-weather and time-tested friend of Pakistan. It is worth mentioning here that crucial Chinese diplomatic support provided an edge to Pakistan and contains India's intentions on forums for India's exemption in Nuclear Suppliers Group (NSG) and India's attempts in the UNSC to designate Pakistani individuals and organizations as terrorists. Among members of the UNSC, China is the only country that supports Pakistan's stance on the Kashmir issue, which is a major constraint for India to pursue its accession intentions. In economic terms, apart from initial investment and aid, Chinese investment of $\$ 62$ billion in infrastructure and energy generation projects have lifted Pakistan from going into turmoil after an economic failure.

Experts and policy makers in public and private sectors commented that Chinese investment projects would have considerable impacts on Pakistan's socio and economic development. Energy projects will generate 17,045 megawatt electricity which will end Pakistan's chronic energy shortfalls, and will give new lifeline to the already exanimate industrial infrastructure. According to a Pakistani newspaper, the CPEC project will generate two million direct jobs in Pakistan within the next two years (The Hindu, 2017). But, despite prospects of hefty benefits in many aspects, the business community sees the CPEC project as a threat to domestic industries if the government does not come up with certain pre-emptive measures to protect vulnerable sectors of the economy. Some segments in business think that the project will be a threat to small and medium enterprises. The business community fears that if the corridor is used only for exports from China without giving certain incentives to Pakistani industry, it will prove damaging to the domestic industrial units (Muhammad, 2016).

The CPEC project also includes construction of educational institutes on its agenda. Several colleges and universities will be built along the corridor. So far, it is confirmed by the Planning Ministry that three universities have been constructed in FATA, Zhob and Gwadar on the western flank of the economic corridor (MPDR, n.d.). Moreover, the construction of Gwadar East-Bay Expressway, the new Gwadar international airport, the dredging of berthing areas and channels, the development of free trade zones, Pakistan-China Friendship Hospital, technical and vocational institutes, Gwadar smart port city, and Gwadar University are in the process of construction (CPEC, 2017). It is expected that successful completion of the projects will turn Gwadar into a smart city attracting international investors.

Similarly, the infrastructure projects will connect major economic nodes of the country as well as connecting Pakistan with China and Central Asian Republics (CARs). The CPEC will connect CARs to South Asia and the Persian Gulf, and will generate substantial revenues in terms of transit fees. Similarly, local farmers and traders will receive major benefits from the transportation of their goods into major markets. An Indian newspaper reported that experts predicted generation of some 700,000 jobs by the year 2030 through the CPEC project (Indian Express, 2016). Boosts to the national economy are expected within the next few years. BMA capital Management Limited analysed the expected impacts on Pakistan's national economy and revealed that the CPEC would increase its GDP growth rate at 1.5 percent in the 
next three years. It would also accelerate private investments and will add share of 1.8 percent in the country's GDP.

China is also expanding its clout through sponsoring scholarships for higher education and establishment of Confucius institutes. Pakistan is the largest beneficiary in South Asia for Chinese funded scholarships. In recent years, China has become a major destination for Pakistani students to pursue higher education after a limited quota offered by western countries. Currently, more than 18,000 students are studying in Chinese universities and many graduates have returned to their home country. They have joined public and private research and development institutions to contribute to social and economic development of the country. They have given a lifeline to research culture in universities and colleges and have provided human capital to the CPEC- related projects. The CSC scholarship program has increased the number of Ph.D holders in Pakistan. Confucius institutes have also enabled Pakistani nationals to understand Chinese culture and arts through learning Mandarin. So far, thousands of Pakistanis have been admitted into Confucius Institutes located in different cities throughout the country to obtain diplomas and degrees in Chinese language. These bilingual nationals are a source for Chinese investors and traders to communicate with the locals.

In short, Chinese soft power strategies have enduring impacts on Pakistan's socio, economic and political structure. An economically strong country is a guarantee to political stability and China has put Pakistan on this track through pouring billions of dollars in infrastructure, energy, health and education sectors. The ruling Junta and general public has been praising Beijing for its unequivocal and timely assistance to save Pakistan from being labelled a failed state.

\section{REFERENCES}

Amin, S. M. (2017, August 16). China's Stance on Kashmir. Retrieved from Pakistan Observer: http://pakobserver.net/chinas-stance-on-kashmir/

Bhattacharjee, D. D. (2015). China-Pakistan Economic Corridor (CPEC). Indian Council of World Affairs.

China.Org.Cn. (2007, April 10). China Launches First Confucius Institute in Pakistan. Retrieved from http://www.china.org.cn/english/education/206705.htm

Chinese Consulate Karachi. (n.d.). Survey on China-Pak Cultural Exchange \& Cooperation. Retrieved from http://karachi.chineseconsulate.org/eng/whjy/t264642.htm

CII. (2005, April). Confucius Institute. Retrieved from National University of Modern Languages: http://www.numl.info/teaching-activities.aspx.

CPEC. (2017). CPEC Projects. Retrieved from http://cpec.gov.pk/special-economiczones-projects 
CRI Confucius Institute. (2010, December 10). Retrieved from http://english.cri.cn/7046/2009/12/10/167s534682.htm.

Daily Times. (2012, May 8). Zardari Appreciated Orient Group for Leading Investment in Pakistan.

Daily Times. (2016, May 23). Karachi's Confucius Institute to help further cement Pak-China friendship. Retrieved from https://dailytimes.com.pk/80745/karachisconfucius-institute-to-help-further-cement-pak-china-friendship/

Dawn News. (2016, March 2). 19,000 Pakistani students studying in Chinese universities. Retrieved from https://www.dawn.com/news/1317973

Dawn News. (2016, January 13). IMF calls for transparency in CPEc projects. Retrieved from Dawn News: https://www.dawn.com/news/1232678

Esteban, M. (2016, July 5). The China-Pakistan Corridor: a transit, economic or development corridor? Elcano Royal Institute.

Global Times. (2015, August 5). A Corridor to Future Development. Retrieved from http://backup.globaltimes.cn/DesktopModules/DnnForge\%20-

$\% 20$ NewsArticles/Print.aspx?tabid=99\&tabmoduleid=94\&articleId=935609\&module $\mathrm{Id}=405 \&$ PortalID,$=0$

Hartpence, M. (2011, July 15). The Economic Dimension of Sino-Pakistan Relations: An Overview. Journal of Contemporary China.

HEC, C. s. (2005, May 30). China Scholarship Council (CSC) signed MOU with Higher Education Commission (HEC) of Pakistan. Retrieved from China Scholarship Council (CSC):

http://en.csc.edu.cn/News/da715f360f75496082ade5429f91f262.shtml

Huang, C. H. (2013, January). China's Soft Power in East Asia: A Quest for Status and Influence? Washington: The National Bureau of Asian Research.

Hussain, K. (2016, September 29). Hidden costs of CPEC. Retrieved from http://www.dawn.com/news/1286698

Indian Express. (2016, April 18). China-Pakistan Economic Corridor: Pakistan's road of high hopes. Retrieved from http://indianexpress.com/article/explained/cpecpakistan-china-nawaz-sharif-xi-jinping-2758111/,

Institute, C. P. (2015). China-Pakistan Economic Corridor-Institutions. Retrieved from http://www.cpecinfo.com/institutions

Jintao, H. (2007, October 15). Hold High the Great Banner of Socialism with Chinese Characteristics and Strive for New Victories in Building a Moderately Prosperous Society in All. Retrieved from http://www.china.org.cn/english/congress/229611.htm\#7 
Kapoor, S. (2015, July 3). China-Pakistan Economic Corridor Will Change the region: Andrew Small. Retrieved from

http://www.hardnewsmedia.com/2015/07/chinapakistan-economic-corridor-willchange-region $\%$ E2\%80\%93-andrew-small

Khan, M. (2016, October 5). Restoration of origional CPEC project demanded. Retrieved from Dawn News:

http://www.dawn.com/news/1288075/restorationoforiginalcpecprojectdemanded

Khan, R. (2016, July 28). CPEC agreement is confidential, Ahsan Iqbal tells Senate. Retrieved from Dawn News: http://www.dawn.com/news/1273776

Khan, U. A. (2016, May 10). Why Pakistanis are among the least innovative in the world. Retrieved from https://www.dawn.com/news/1257273

Kiani, K. (2015, April 21). \$28 bn accords for fast track projects. Retrieved from http://www.dawn.com/news/1177233/28bn-accords-for-fast-track-projects

Kumar, A. (2006). China-Pakistan Economic Relations. Institute of Peace and Conflict Studies (IPCS).

Kurlantzick, J. (2006, June). China's Charm: Implications of Chinese Soft Power. Carnegie Endowment for International Peace, 47.

Li, H. (2015, April 20). Press Conference of Ministry of Foreign Affairs of the Peoples Republic of China.

Memon, D. N. (2010, September). Pak-China Economic and Trade Relations. PTJ.

Miller, G. (2011, May 6). CIA spied on bin Laden from Safe House. The Washington Post. Retrieved from https://www.washingtonpost.com/world/cia-spied-on-bin-ladenfrom-safe-house/2011/05/05/AFXbG31F_story.html?utm_term=.888ead278d59

MOFA PRC. (n.d.). Cultural Agreement between the Governments of the People's Republic of China and the Islamic Republic of Pakistan. Important Documents and Relations between the People's Republic of China and Islamic Republic of Pakistan. Beijing, China: Ministry of Foreign Affairs.

MPDR, G. (n.d.). Three Universities on Western Route of CPEC will start functioning this years. Retrieved from http://www.pc.gov.pk/?p=5723

Muhammad, P. (2016, November 20). The Express Tribune. CPEC project: Nascent industries afraid of big Chinese firms. Retrieved from https://ribune.com.pk/story/1237534/cpec-project-nascent-industries-afraid-bigchinese-firms/

Murphy, B. S. (2009, March 10). Soft Power with Chinese Characteristics. Center for Strategic \& International Studies (CSIS). 
Naveed, J. R. (2014, December). Pakistan-China Social and Economic Relations. Journal of South Asian Studies.

National Development and Reform Commission. (2015, March). Vision and Actions on Jointly Building Silk Road Economic Belt and $21^{\text {st }}$ Century Maritime Silk Road. Retrieved from http://en.ndrc.gov.cn/newsrelease/201503/t20150330_669367.html.

Niazi, A. (2018, February 20). Pakistan Today. Senate snubs Indian media's claims that 'Chinese is Pakistan's third official language'. Retrieved from https://www.pakistantoday.com.pk/2018/02/20/senate-snubs-indian-medias-claimsthat-chinese-is-pakistans-third-official-language/

Nihao Salam. (2016). Lean Chinese. October 18, 2016. Retrieved from Nihao-Salam: http://www.nihao-salam.com/Learn-Chinese.php

Nye, J. S. (2004). Soft Power The Means to Success in world Politics. New York: BBS Public Affairs.

Observer, P. (2015). 500 Punjab Students to Learn Chinese. Retrieved from http://pakobserver.net/2016/04/11/500-punjab-students-to-learn-chinese/

Pakistan Today. (2017, January 4). CPEC to generate 2.32 million jobs within next two years. Retrieved from https:/www.pakistantoday.com.pk/2017/01/04/cpec-togenerate-2-32-million-jobs-within next-2 years/

Pant, H. V. (2012, Winter). The Pakistan Thorn in China-India-U.S. Relations. The Washington Quarterly.

Patranobis, S. (2017, May 11). Hindustan Times. Beijing gearing up to meddle in kashmir through CPEC, says Chinese media. Retrieved from http://www.hindustantimes.com/world-news/beijing-gearing-up-to-meddle-inkashmir-through-cpec-says-chinese-media/story-oixzZYSY8kgmRsWnWD

Peoples Daily. (2004, December 21). Culture Minister on China's Foreign Exchange. Retrieved from http://en.people.cn/200412/21/eng20041221_168135.html

Peoples Daily. (2009, September 10). China-Pakistan Service Trade Agreement to take effect next month. Retrieved from http://en.people.cn/90001/90776/90884/6754303.html

Rediff News. (2015, April 20). China and Pakistan just did something that will anger India. Retrieved from http://www.rediff.com/news/report/china-and-pakistan-just-didsomething-will-anger-india/20150420.htm

Roche, E. (2016, October 17). Why is Masood Azhar so important to China? . Retrieved from https://www.livemint.com/Politics/h074H8BmzsTgo2Jh1eE3xK/AtUN-China-twice-blocked-Indias-bid-to-ban-JeM-chief-Maso.html

SATP. (2017). Fatalities in Terrorist Violence in Pakistan 2003-2017. Retrieved from http://www.satp.org/satporgtp/countries/pakistan/database/casualties.htm 
Sayama, O. (2016, March). China's Approach to Soft Power: Seeking a balance between Nationalism, Legitimacy and International Influence. Royal United Services Institute (RUSI).

Schools, R. I. (2016). Roots Chinese Language Department (RCLD). Retrieved from $\mathrm{http} / /$ www.rootsinternational.edu.pk/chinese-language/index.html

Shah, S. (2015, April 20). The Wall Street Journal. China's Xi Jinping Launches Investment Deal in Pakistan. Retrieved from http://www.wsj.com/articles/chinas-xijinping-set-to-launch-investment-deal-in-pakistan-1429533767

Sharma, R. (2014, December 4). First Post. Waving the red rag at India: China describes disputed PoK region as Pakistan. Retrieved from http://www.firstpost.com/world/waving-the-red-rag-at-india-china-describesdisputed-pok-region-as-pakistan-1833635.html

Sial, S. (2014). The China-Pakistan Economic Corridor: An Assessment Potential threats and constraints. Peace and Conflict Studies.

Siddique, Q. (2014). Deeper than the Indian Ocean? An Analysis of Pakistan-China Relations. Center for International and Strategic Analysis.

Siddiqui, R. A. (2014). China's Evolving Posture in South Asia: Some Reflections. IPRI Journal.

Siddiqui, S. (2017, April 12). The Express Tribune. CPEC Investment pushed from $\$ 55 b$ to $\$ 62 b$. Retrieved from https://tribune.com.pk/story/1381733/cpec-investmentpushed-55b-62b/

Singh, B. (2016, April 13). China's Veto War. Sunday Chronicle. Retrieved from http://www.deccanchronicle.com/opinion/columnists/130416/china-s-veto-wars.html

Small, A. (2010). China's Caution on Afghanistan-Pakistan. The Washington Quarterly.

Small, A. (2015). The China-Pakistan Axis: Asia's New Geopolitics. United Kingdom: Oxford University Press .

Talwar, S. (2015, June 22). China-Pakistan Economic Corridor and Its Geo-Political Implications. Centre for Air Power Studies (CAPS).

The Hindu. (2017, February 7). India in talks with China over repeated blocks in designating Masood Azhar. Retrieved from

http://www.thehindu.com/news/national/India-in-talks-with-China-over-repeatedblocks-in-designating-Masood-Azhar/article17242575.ece

The New York Times. (2015, April 23). China's Big Plunge in Pakistan. Retrieved from http://www.nytimes.com/2015/04/23/opinion/chinas-big-plunge-inpakistan.html?_r=1 
Tribune, T. E. (2016, June 24). Admissions Open: Chinese Universities teaching $U r d u$. Retrieved from https://tribune.com.pk/story/1129157/admissions-open-chineseuniversities-teaching-urdu/

United Nations. (1945). Charter of the United Nations and Statute of the International Court of Justice. San Francisco.

Wang, Y. (2008, March). Public Diplomacy and the Rise of Chinese Soft Power. The Annals of The Anerican Academy, AAPSS.

Yang, R. (2010). Soft Power and higher education: an examination of China's Confucius Institutes. Globalisation, Societies and Education, 8(2).

Yang, R. (2015). China's Soft Power Projection in Higher Education. 